\title{
The Effects of Combined Application of Cattle manure And Mineral Nitrogen And Phosphorus Fertilizer on Growth, Biomass Yield, And Quality of Potato (Solanum Tuberosum $L$ ) Tuber in Abelo area at Masha District sheka Zone, South-Western Ethiopia
}

\author{
Isreal Zewide ${ }^{1 *}$, Tamado Tana ${ }^{2}$, Lemma Wog ${ }^{3}$ and Ali Mohammed ${ }^{4}$ \\ ${ }^{1}$ Mizan-Teppi university, department of horticulture P.O, Box 260, MizanTeferi, Ethiopia \\ ${ }^{2}$ Haramaya University, school of plant sciences P.O, Box 138, Dire Dawa Ethiopia
}

${ }^{3}$ Haramaya UniversitySchool of Natural Resources Management and Environmental Sciences, P.O, Box 138 Dire Dawa Ethiopia

${ }_{4}^{4}$ Jimma University College of Agri. and Vet. Medicine, Department of Post-harvest Management, P.O.Box 37, Jimma Ethiopia

\begin{abstract}
Received: January 29, 2018; Accepted: February 12, 2018; Published: March 15, 2018
*Corresponding author: Isreal Zewide, department of horticulture, Mizan-Teppi the university MizanTeferi, Ethiopia. E-mail : zewideisreal@ gmail.com
\end{abstract}

\begin{abstract}
Soil fertility decline is considered as one of the major causes for resulting in reduced yield of potato production in abelo area Masha district sheka zone of south-western Ethiopia. Hence, a field experiment was conducted in Belgand Meher season, in abelo area, Masha district south-western Ethiopia, to investigate the effect of combined use of application of Cattle Manure (CM) with mineral NP on growth, biomass yield, quality, of potato tuber. The treatments comprised combinations of three rates $\left(2.5,5,7.5 \mathrm{t} \mathrm{ha}^{-1}\right)$ of CM with $25 \%, 50 \%$ and $75 \%$ of recommended rates of mineral NP, respectively. In addition, $100 \%$ recommended rate of mineral NP for the experimental site $(165 \mathrm{~kg} \mathrm{~N}$ $\mathrm{ha}^{-1}$ and $137 \mathrm{~kg} \mathrm{P}_{2} \mathrm{O}_{5} \mathrm{ha}^{-1}$ ) and zero rates were used for comparison. The experiment was laid out in a randomized complete block design with three replications.The results revealed that applying $7.5 \mathrm{t} \mathrm{ha}^{-1}$ CM combined with $75 \%$ mineral NP gave significantly Days to $50 \%$ flowering by 7 daysi.e. From 56-6 and 14 daysi.e. from 51-65, days to $50 \%$ maturity by 5 daysi.e. from (101-106) and 13 days from (95108 ) and increases plant height from 56-69 and 63-78, Increase shoot fresh weight by $39.66 \%$ from (1274.59- 1780.2 ghill- $^{-1}$ ) and $36.66 \%$ from (1213.91 -1658.99 ghill $\left.^{-1}\right)$ and shoot dry weight by $46.8 \%$ from ( 40.4 ghill-1 to 59.333 ghill- $^{-1}$ ) and $41.66 \%$ from ( 40 to 56.667 ghill$\left.{ }^{1}\right)$,increased dry matter content from (21.085-25.782) and (22.36 to 24.47), specific gravity from (1.083- 1.107) and (1.092 -1.101) reduces small tuber size percentage Form (27.306 to 17.069) and (43.946 -14.267) and improves medium size tubers from (65.56 to 74.79 ) and (44.58 to 80.26) in Belg and Meher season as compared to zero application. Respectively. Therefore, it can be concluded that, the use of combined application of CM $\left(7.5 \mathrm{t} \mathrm{ha}^{-1}\right)$ together with $75 \%$ of recommended rates of mineral NP $\left(123.75 \mathrm{~kg} \mathrm{~N}^{-1}\right.$ and $103.05 \mathrm{~kg} \mathrm{P}_{2} \mathrm{O}_{5}$ ha $^{-1}$ ) can significantly increases growth, biomass yield, improvement in tuber quality.
\end{abstract}

Keywords: Biomass Yield; Cattle Manure; Nitrogen; Phosphorous;

Tuber Quality

\section{Introduction}

Potato(Solonaumtuberosum L.) Which belongs to the Solanaceae, family,genus Solanum which also includes tomato eggplant and pepper etc is one of the most important tuber crops in the world. It is a cool-season crop, most dependable and early maturing root and tuber crop

Potato tuber consists of main carbohydrates, proteins, and lipids. The tuber is used locally alone or with meat, and vegetables as substituent with pulse in stew preparation in Sheka Zone, southwestern Ethiopia, the potato is one of the widely grown and major cultivated tuber crops. It is a preferable crop in the study area due to that it can be produced more than twice per year [1].

Inadequate agronomic management practices specifically, inadequate and inappropriate application of fertilizers, low nutrient reserves in arable soils, a negative nutrient balance on cropland by potato growers are factors Contributing to the low yield of potato in study areas. Potato is one of the heavy feeders requiring relatively large quantities of fertilizers. However, scarcity use of only chemical fertilizers without supplementing with organic sources due to the high cost of chemical fertilizers and limited availability for the smallholder farmers accompanied with a high amount of rainfall that might have caused leaching of macro- and micro-nutrients significantly reduced soil fertility and crop productivity in the study area.

In addition to the high cost, use of mineral fertilizers constantly lead to decline soil chemical and physical properties, biological activities and thus, overall, the total soil health $[2,3,4]$. 
Due to this, nutrients supplied exclusively through chemical sources, though enhance yield initially, and lead to unsustainable productivity over the years [2,5]. Thus, the undesirable impacts of chemical fertilizers, coupled with their high prices, have prompted the interest in the use of organic fertilizers as a source of nutrients. The combined use of Organic together with mineral fertilizer application has been reported to improve crop growth by supplying plant nutrients including micro-nutrients as well as improving soil physical, chemical, and biological properties thereby provide a better environment for root growth by improving the soil structure $[6,7]$.

Many research findings have shown that neither mineral fertilizers nor organic sources alone can result in sustainable productivity $[5,8,9]$. Furthermore, the price of mineral fertilizers is increasing and becoming unaffordable for resourcepoor smallholder farmers. The best remedy for soil fertility management is, therefore, a combination of both mineral and organic fertilizers, where the mineral fertilizer provides readily available nutrients and the organic fertilizer mainly increases soil organic matter and improves soil structure and buffering capacity of the soil [9]. The combined application of mineral and organic fertilizers, usually termed as integrated nutrient management, is widely recognized as a way of increasing yield and or improving the productivity of the soil sustainably $[47,39]$. Several researchers $[2,10,11,12]$ have verified the beneficial effect of integrated nutrient management in moderating the deficiency of a number of macros- and micro-nutrients. In view of this fact, identifying the optimum dose of integrated nutrients application is crucial and is required for maintaining sufficient amount of nutrients for increased yield of the crop.

Cattle manure is adecayed mixture of the dung and urine of cattle or other livestock with the straw and litter used as bedding and residues from the fodder fed to them. Whatever is collected for manuring is usually heaped on the ground surface with residues from fodder and other house sweepings. The nitrogen in the manure is subject to volatilization and leaching losses and the material that finally will be spread on the field may have low nitrogen content. The application of well-decomposed manure is more desirable than using fresh materials $[13,14]$.

reported high tuber yield of potato was obtained when CM (cattle manure) at the rate of $10 \mathrm{qha}^{-1}$ was combined with mineral nitrogen at $111 \mathrm{~kg} \mathrm{t} \mathrm{ha}^{-1}$ and phosphorous at $90 \mathrm{~kg} \mathrm{P}_{2} \mathrm{O}_{5} \mathrm{ha}^{-1}$ on Nitosol, of Bako Ethiopia[15].

reported that the highest potato tuber yield was attained by combined Application of $15 \mathrm{t} \mathrm{ha}^{-1} \mathrm{CM}$ with the application of $100 \%$ recommended rate NPK $\left(100^{-1} 00^{-1} 00 \mathrm{~kg} \mathrm{ha}^{-1}\right)$ and NP $(100 / 100$ $\mathrm{kg} \mathrm{ha}^{-1}$ ) increased tuber yield over control by 567.9 and $393.9 \%$, respectively as compared to the application of organic or mineral fertilizers in isolation[16].

stated that application of $30 \mathrm{t} \mathrm{ha}^{-1}$ cattle manure along with nitrogen at $120 \mathrm{~kg} \mathrm{~N} \mathrm{ha}^{-1}$ and phosphorous at $92 \mathrm{~kg} \mathrm{P}_{2} \mathrm{O}_{5} \mathrm{ha}^{-1}$ gave yield advantage of $8.4 \mathrm{t} \mathrm{ha}^{-1}$ in North-Eastern Ethiopia. In addition, Isreal etal 2012 recomende $165 \mathrm{Kg} \mathrm{N}$ and $60 \mathrm{Kg} \mathrm{P} 205$ is optimum for potato production at masha districets outhe westen Ethiopia [17].

However, research on integrated nutrient management for potato production has not been yet conducted at Masha district Sheka Zone, southwestern Ethiopia. Thus, this study was conducted to determine the effect of combined application of CM with mineral NP fertilizers on the growth, yield components, yield of potato and physico-chemical characteristics of the soil, and to determine appropriate rates of combined $\mathrm{CM}$ with mineral NP fertilizers for better productivity of the potato.

\section{Materials and Methods}

\section{Description of the study site}

The experiment was conducted at the abelo area in Masha district of Sheka Zone, southwestern Ethiopia, in 2016 main cropping season from Belg (February- to May) and Meher (June to October). The study site of Masha district located at UTM WGCs 1984 Zone 36N between 861,000MN - 873,000MN latitude and 105,000 - ,000ME. Longitude Attitudinally1642 to 2025 m.a.s.l (Isreal et al 2018)

The rainfall pattern of these areas is characterized by monomodal distribution with small rainy season in Belg (February -May) and main rainy season's Meher (June October) [65].

\section{Experimental materials}

A potato variety called 'Belete' was used as a test crop. The variety was released in 2009 by Holeta Agricultural Research Center, Ethiopia, for its high yield and promising agronomic performances. The variety matures in $90^{-1} 20$ days. The yield ranges from $29.13 \mathrm{t} \mathrm{ha}^{-1}$ under farmers $44.8 \mathrm{t} \mathrm{ha}^{-1}$ under research Source (MARD, et, al 2012)

Potato variety Belete, obtained from Holleta Agricultural Research Center, was used for the experiment. Belete is one of the potential potato cultivars for south-west highlands such as Masha woreda and it has the following characteristics (Table 2.1).

Urea $(46 \% \mathrm{~N})$ and TSP $\left(46 \% \mathrm{P}_{2} \mathrm{O}_{5}\right)$ were used as mineral $\mathrm{N}$ and $\mathrm{P}$ sources whereas Cattle manure was used as an organic fertilizer. Cattle manure was collected from those farmers trained and supervised by the teppi soil testing research Centre under the financial aid of Sustainable Land Management (SLM) project in Mashadistinct Sheka Zone; Urea and TSP were collected from Teppi Soil Testing Research Center.

\section{Treatments and experimental design}

The treatments consisted of combinations of three rates of CM $\left(2.5,5,7 \mathrm{tha}^{-1}\right)$ and with three rates $(25 \%, 50 \%$, and $75 \%)$ of recommended mineral NP fertilizers. In addition, 100\% recommended rate of mineral NP fertilizer for specific site (165 kg N ha-1 and $60 \mathrm{~kg} \mathrm{P}_{2} \mathrm{O}_{5} \mathrm{ha}^{-1}$ ) and zero rates were used for comparison. Thus, there were 11 treatments. Where $\mathrm{T} 1=$ Control, 
$\mathrm{T} 2=100 \%$ RDF, T3=2.5t CM+25\%RDF, $\mathrm{T} 4=2.5 \mathrm{tCM}+50 \%$ RDF, T5 $=2.5 \mathrm{tCM}+75 \% \mathrm{RDF}, \mathrm{T} 6 .=5 \mathrm{t} \mathrm{CM}+25 \% \mathrm{RDF}, \mathrm{T} 7=5 \mathrm{t} \mathrm{CM}+50 \% \mathrm{RDF}$, T8. $=5 \mathrm{t} \mathrm{CM}+75 \%$ RDF, $\mathrm{T} 9=7.5 \mathrm{t} \mathrm{CM}+25 \%$ RDF, $\mathrm{T} 10=7.5 \mathrm{t} \mathrm{CM}+50 \%$ $\mathrm{RDF}, \mathrm{T} 11=7.5 \mathrm{t} \mathrm{CM}+75 \% \mathrm{RDF}$ the experiment was laid out in a randomized complete block design with three replications.

Each block and plots within ablock were spaced $1 \mathrm{~m}$ and 0.5 $\mathrm{m}$ apart, respectively. Each plot had 12 rows of $75 \mathrm{~cm}$ apart each with $3.6 \mathrm{~m}$ length. The gross plot size was, therefore, $3.6 \mathrm{~m} \times$ $4.5 \mathrm{~m}\left(16.2 \mathrm{~m}^{2}\right)$. The first rows from each side of the plots were considered as a border. The second rows from each side of the plot were designated as sampling rows. In each plot, 1.5 and 0.6 $m$ row length at the end of each row and column were left as a border to avoid the border effect. Therefore, the net plot size was $3 \mathrm{~m} \times 3 \mathrm{~m}\left(9 \mathrm{~m}^{2}\right)$.

\section{Soil sampling and analysis}

Before planting, surface $(0-20 \mathrm{~cm})$ soil samples, from five spots across the experimental fields, were collected in a zigzag pattern, composited and analyzed for soil physico-chemical properties and the results are depicted in Table 2.2. The soil sample was air dried and crushed to pass through a 2-mm mesh size and soil physico-chemical properties were analyzed in Teppi soil testing laboratory, following the procedures depicted below.

Soil texture was determined using Bouyoucos hydrometer method [20]; soil $\mathrm{pH}$ and electrical conductivity of the soils were measured in water (1: 2.5 soil: water ratio). by digital $\mathrm{pH}$ and Ec meter[21]; soil organic carbon by wet digestion method and total $\mathrm{N}$ by Kjeldhal method[23,24]. Available phosphorous was determined by the Cation Exchange Capacity (CEC) was determined using $1 \mathrm{M}$-neutral ammonium acetate $[25,26]$.

Exchangeable acidity ( $\mathrm{Al}$ and $\mathrm{H}$ ) was determined by saturating the soil samples with $1 \mathrm{M} \mathrm{KCl}$ solution and titrated with $0.02 \mathrm{M}$ $\mathrm{NaOH}$ as described by [27]. From the same extract, exchangeable $\mathrm{Al}$ was titrated with standard solution of $0.02 \mathrm{M} \mathrm{HCl}$. Finally, exchangeable $\mathrm{H}$ was obtained by subtracting exchangeable $\mathrm{Al}$ from exchangeable acidity $(\mathrm{Al}+\mathrm{H})$

\section{Experimental procedures}

In order to have fine seedbed for good root development, the experimental field was plowed three times using a pair of oxen and the plots were leveled manually. Cattle manure (CM) was applied on dry weight basis three weeks before to planting and totally mixed with the soil in the field. The potato tuber was planted in rows spaced $30 \mathrm{~cm}$ apart by hand drilling at the seed rate of $20 \mathrm{q} \mathrm{ha}^{-1}$ in the first week of February 2016.

\section{Crop data collection}

Data on crop phenology, growth, yield components and yield were measured from randomly selected plants on a plot basis. Net plot size was used for measuring yield and yield components of potato. The data recording and measurements for each character were carried out as follows.

\section{Phenological parameters}

Days to $50 \%$ flowering: it was recorded as the number of days from planting when $50 \%$ of the plants in each plot produced flowers.

Days to $50 \%$ physiological maturity: it was recorded when $50 \%$ of leaves from different treatments were turned to yellow.

\section{Growth parameters}

Average stems number per hill: the actual numbers of main stems per hill were recorded as the average stem count of five hills per plot at $50 \%$ flowering. Only stems that emerged independently above the soil as single stems were considered as main stems. Stems branching from other stems above the soil were not considered as main stems.

Plant height $(\mathrm{cm})$ : refers to the height from the base to the apex of the plant. It was measured using a measuring tape at $90 \%$ physiological maturity from the main stem originating directly from mother tubers to the apex of the plant by taking five sample plants from each plot.

\section{Tuber quality attributes}

Tuber size distribution in weight: at harvest, tubers were collected from five randomly selected plants from each plot and were categorized as small (25-38g); medium (39-75g); and large ( $>75 \mathrm{~g}$ ) [28]. The proportion of the weight of tubers in the different tuber size categories was converted to percentages.

Tuber dry matter content (\%): five potato tubers were randomly selected from each plot, chopped into small $(1-2 \mathrm{~cm}$ cubes), mixed fully, and two fresh sub-samples each weighing $200 \mathrm{~g}$ were taken for drying to a constant weight. To each subsample was placed in a paper bag and put in an oven at 70 OC for 72 hours. Each sub-sample was immediately weighed and the mean was recorded as dry weight. Percent dry matter content for each sub-sample was calculated based on the formula described by [29].

$$
\operatorname{DM}(\%)=\frac{W A D^{*} 100}{I W}
$$

where WAD = Weight of sample after drying in (g); Iw = Initial Weight of the sample (g)

The specific gravity of tubers: this was determined by the weight of air and weight in water method. Five kilograms of tubers of all shapes and sizes were randomly chosen from each plot. The wanted tubers were washed with water. The samples were then being first weighed in air and then re-weighed suspended in water. Specific gravity was computed using the following formula which developed by [2].

$$
S g=\frac{W a}{W a-W w}
$$

where $\mathrm{Sg}=$ Specific gravity; $\mathrm{Wa}=$ Weight in the air; $\mathrm{Ww}=\mathrm{Weight}$ in water 


\section{Statistical data analysis}

The agronomic data were subjected to analysis of variance (GLM procedure) using SAS software program version 9.2 [30]. Homogeneity of variances was calculated using the F-test as described by Gomez and Gomez (1984) and since the F-test has shown heterogeneity of the variances of the two seasons for all of the agronomic parameters, a separate analysis was used for the two seasons. The Fisher's protected Least Significant Difference (LSD) test at 0.05 probability level was employed to separate treatment means where significant treatment differences occurred.

\section{Results and Discussion}

\section{Initial Soil Properties and Cattle Manure Compositions}

These results of the initial soil test analysis showed that the soils at the sites were low in fertility, acidic, with low amounts of total N, organic carbon, total and extractable phosphorous and exchangeable bases (Table 2.5). This could be attributed to the poor management of crop residue, thus resulting in nutrient reduction and the decline in soil fertility. The crop response to added organic and mineral fertilizer at different season is expected to show responses on crops and soils

Prior to planting, surface $(0-20 \mathrm{~cm})$ soil samples, from five spots across the experimental fields, were collected in a zigzag pattern, in 2016 Belgand Meher cropping seasons composite, and analyzed in teppi soil testing, research Centre for soil physicochemical properties as per the procedures given in the results are depicted in (Table 2.2).

Analysis of composition of soil and cattle manure reveled better nutrient composition in Belg than in Meher season (Table 2 and 3 )

Farmers in masha mostly use cattle manure as the organic source. The de- composition rate of these materials in soil depends on the chemical composition of the material (C: $\mathrm{N}$ ratio), soil temperature, soil moisture, method of application (surface applied, soil incorporated, etc.), and rate of application.

The soil physico chemical analysis of the study sites revealed that the soils of the experimental field were sandy clay loam in texture in both Belg and Meher cropping season. The results also indicated that the soil of Belg and Meher cropping season are strongly and very strongly acidic with $\mathrm{pH}$ of 5.2 and 4.8, respectively. The soils have low organic carbon, total $\mathrm{N}\left(\mathrm{g} \mathrm{kg}^{-1}\right)$ and available $\mathrm{P}$ (ppm) and medium in exchangeable base except trace in sodium, CEC and high in micronutrient cation $\mathrm{Fe} \mathrm{Mn} \mathrm{Cu}$ Zn both in Belg and Meher season

The soil physicco-chemical analysis of the study areas revealed that the soils of the experimental field were sandy clay loam in texture in both Belg and Meher season in abelo area with $\mathrm{pH}$ of 5.01(Strongly acidic) in Belg season and 4.8 (Very Strongly acidic) in Meher season

The soil had also relatively high content of exchangeable acidity and aluminum (3.83and $3.82 \mathrm{cmolc}^{-1}$ ) in belg and $\mathrm{Al}$ (2.01 and 2.46) $\mathrm{cm} \mathrm{olc} \mathrm{kg}^{-1}$ ). In mehre season

The soils of both study sites have medium CEC of $20 \mathrm{Cmol}(+)$ $\left.\mathrm{kg}^{-1}\right)$ in Belg season and $\left.19.3 \mathrm{cmol}(+) \mathrm{kg}^{-1}\right)$, in Mehre season low organic carbon content of 1.2 and $1.15\left(\mathrm{~g} \mathrm{~kg}^{-1}\right.$ and Following the rating of total $\mathrm{N}$ of $<0.05 \%$ as very low, $0.05-0.12$ low, 0.12 0.25 Medium, $>0.25$ high N status as indicated the surface Soils of both the Belg and Meherseason qualify low status of N. low total $\mathrm{N}$ of 0.1 and $0.08\left(\mathrm{~g} \mathrm{~kg}^{-1}\right.$ content in Belg and Mehre season , respectively The analysis also revealed that the available $\mathrm{P}$ of the soils was 5.5and $5 \mathrm{ppm}$ in Belge andMeher, season respectively. Thus, the soils of the experimental sites are low in available $\mathrm{P}$ content both in Belge and Meher season (Table 2.2) according to the rating of [31].

Just after harvesting the crop, composite surface $(0-20$ $\mathrm{cm}$ ) soil samples were collected from three spots for each plot from every replication. These samples were composited to yield one representative sample per replication from each plot for determination of $\mathrm{CEC}, \mathrm{pH}$, total $\mathrm{N}$, available $\mathrm{P}$, available $\mathrm{K}$ and organic carbon contents using procedures indicated for presowing soil analysis. The extract of $\mathrm{K}$ was analyzed using flame photometer [32]. The bulk density (Db) of the soil was measured from the undisturbed soil samples collected from each plot using core sampler, which was weighed at field moisture, and after drying the pre-weighed core soil sample to a steady weight in an oven at $105^{\circ} \mathrm{C}$ according to the procedure described by (Okalebo et, al.) while particle density ( $\mathrm{ps}$ ) was measured using psychnometer [33].

$$
\text { Totalporosity }(\%)=\left[1-\left(\frac{B D}{P D}\right)\right] * 100
$$

where, $\mathrm{BD}=$ =bulk density; $\mathrm{PD}=$ particle density(Hillel, 2004).

Cattle manure Because of its alkalinity and elevated contents of alkali and alkaline earth elements, cattle manure can be utilized to raise the $\mathrm{pH}$ of acid soils [34]. Therefore, cattle manure can be used as an alternative to lime either by itself or as a mixture of mineral NP. The cattle manure in Belg season has also relatively higher content of total $\mathrm{P}$ compared to cattle manure in Mehre season

The organic carbon, N, P, KpH,Electrical conductivity,Total Ca, Total Mg,Total K,Total Na, CEC and moisture contents of the CM at different seasonused in the experiments were determined and depicted in Table 2.2.

\section{Phonological and growth parameters}

Effect of combined use of cattle manure and mineral NP on growth and phonological parameter the result of the present study showed There was a significant difference $(p<0.05)$ in the number of days to flowering maturity and plant height due to the application of different rates of CM in combination with rates of mineral NP both in Belg and Mehere seasons Though, the application of fertilizers non-significantly $(\mathrm{P}>0.05)$ affects steam number/hill in both Belg and Mehre season as compared to zero fertilizer application (Table 4). 
The Effects of Combined Application of Cattle manure And Mineral Nitrogen And Phosphorus Fertilizer on Growth, Biomass Yield, And Quality of Potato (Solanum Tuberosum L) Tuber In abelo Area at Masha District sheka Zone, South-Western Ethiopia

Table 1: Some characteristics of potato variety Belte

\begin{tabular}{|c|c|c|c|c|c|c|c|}
\hline \multirow[t]{2}{*}{ Variety } & \multirow[t]{2}{*}{ Year of release } & \multirow[t]{2}{*}{ Research station } & \multirow[t]{2}{*}{ Altitude m.a.s. 1} & \multirow[t]{2}{*}{ Rainfalls (mm) } & \multirow[t]{2}{*}{ Maturity (days) } & \multicolumn{2}{|c|}{ Yield (tha- ${ }^{1}$ ) } \\
\hline & & & & & & Research & Farmers \\
\hline Belte & 2009 & Holleta & $1600-2800$ & $750-1000$ & $90-120$ & 44.8 & 29.13 \\
\hline
\end{tabular}

Table 2: Selected physic-chemical characteristics of soil of the experimental sites

\begin{tabular}{|c|c|c|c|c|c|}
\hline Soil parameters & $\begin{array}{c}\text { Soil Belg (short rain } \\
\text { season-February to May) }\end{array}$ & Rating & $\begin{array}{c}\text { Soil Maher (long rain } \\
\text { season-June to October) }\end{array}$ & Rating & References \\
\hline $\mathrm{Bd}\left(\mathrm{g} \mathrm{cm}^{-3}\right)$ & 1.37 & Medium & 1.38 & Medium & $\begin{array}{c}\text { Barauah and } \\
\text { Barthakulh,(1997) }\end{array}$ \\
\hline $\mathrm{PD}\left(\mathrm{g} \mathrm{cm}^{-3}\right)$ & 2.58 & Medium & 2.6 & Medium & $\begin{array}{c}\text { Barauah and Barthakulh, } \\
\text { (1997) }\end{array}$ \\
\hline \%porosity & 46.8 & & 46.92 & & Hillel, (2004). \\
\hline$\%$ Sand & 57 & - & 56 & - & \\
\hline$\%$ Slit & 18 & - & 16 & - & \\
\hline $\mathrm{pH}$ & 5.01 & $\begin{array}{l}\text { Strongly } \\
\text { acidic }\end{array}$ & 4.8 & $\begin{array}{l}\text { Very strongly } \\
\text { acidic }\end{array}$ & Tekalignet al. (1991) \\
\hline $\mathrm{EC}(\mathrm{us} / \mathrm{cm})$ & 169 & Very low & 85 & Very low & EthioSIS (2014) \\
\hline $\mathrm{N}\left(\mathrm{g} \mathrm{kg}^{-1}\right)$ & 0.1 & Low & 0.08 & Low & Tekalignet al. (1991) \\
\hline $\begin{array}{l}\text { Exchangeable Ca } \\
\left(\mathrm{Cmol}(+) \mathrm{kg}^{-1} \text { soil }\right)\end{array}$ & 6.5 & Medium & 6.3 & Medium & FAO (2006) \\
\hline $\begin{array}{l}\text { Exchangeable Mg } \\
\left(\mathrm{Cmol}(+) \mathrm{kg}^{-1} \text { soil }\right)\end{array}$ & 2.1 & Moderate & 1.4 & Moderate & FAO $(2006$ \\
\hline $\begin{array}{c}\text { Exchangeable K } \\
\left(\mathrm{Cmol}(+) \mathrm{kg}^{-1} \text { soil }\right)\end{array}$ & 0.42 & High & 0.36 & High & FAO (2006) \\
\hline $\begin{array}{l}\text { Exchangeable Na } \\
\left(\mathrm{Cmol}(+) \mathrm{kg}^{-1} \text { soil }\right)\end{array}$ & 0.06 & Very low & Nill & Very low & Landon (1991) \\
\hline $\begin{array}{l}\mathrm{CEC}\left(\mathrm{Cmol}(+) \mathrm{kg}^{-1}\right. \\
\text { soil })\end{array}$ & 20 & Medium & 19.3 & Medium & $\begin{array}{l}\text { Hazelton and Murphy } \\
\text { (2007) }\end{array}$ \\
\hline Pbs (\%) & 45.4 & Medium & 41.7 & Medium & $\begin{array}{l}\text { Hazelton and Murphy } \\
\text { (2007) }\end{array}$ \\
\hline $\begin{array}{c}\text { Exchangeable Al } \\
\left(\mathrm{Cmol}(+) \mathrm{kg}^{-1} \text { soil }\right)\end{array}$ & 2.01 & High & 2.46 & High & $\begin{array}{l}\text { Hazelton and Murphy } \\
\qquad(2007)\end{array}$ \\
\hline $\begin{array}{l}\text { Exchangeable acidity } \\
\left(\mathrm{Cmol}(+) \mathrm{kg}^{-1} \text { soil }\right)\end{array}$ & 3.83 & High & 3.82 & High & $\begin{array}{l}\text { Hazelton and Murphy } \\
\qquad(2007))\end{array}$ \\
\hline O.C $\left(\mathrm{g} \mathrm{kg}^{-1}\right)$ & 1.2 & Low & 1.02 & Low & Tekalignet al. (1991) \\
\hline $\mathrm{N}\left(\mathrm{g} \mathrm{kg}^{-1}\right)$ & 0.1 & Low & 0.08 & Low & Tekalignet al. (1991) \\
\hline $\mathrm{C}: \mathrm{N}$ & 12 & Low & 12.75 & Low & $\begin{array}{l}\text { Hazelton and Murphy } \\
\qquad(2007)\end{array}$ \\
\hline Available $\mathrm{P}\left(\mathrm{mg} \mathrm{kg}^{-1}\right)$ & 5.5 & Low & 5 & Low & Jones, J. Benton (2003) \\
\hline $\mathrm{Cu}\left(\mathrm{mg} \mathrm{kg}^{-1}\right)(\mathrm{DTPA})$ & 8 & High & 6 & High & Jones, J. Benton (2003) \\
\hline $\mathrm{Fe}\left(\mathrm{mg} \mathrm{kg}^{-1}\right)(\mathrm{DTPA})$ & 120 & High & 80 & High & Jones, J. Benton (2003) \\
\hline $\mathrm{Zn}\left(\mathrm{mg} \mathrm{kg}^{-1}\right)(\mathrm{DTPA})$ & 1.5 & High & 1.2 & High & Jones, J. Benton (2003) \\
\hline $\operatorname{Mn}\left(\mathrm{mgkg}^{-1}\right)(\mathrm{DTPA})$ & 25 & High & 20 & High & Jones, J. Benton (2003) \\
\hline
\end{tabular}


The Effects of Combined Application of Cattle manure And Mineral Nitrogen And Phosphorus Fertilizer on Growth, Biomass Yield, And Quality of Potato (Solanum Tuberosum L) Tuber In abelo Area at Masha District sheka Zone, South-Western Ethiopia

Table 3: Organic matter, N, P, K, pH, Total N, Ca, Mg, K, Na, CEC, EC and moisture content of the substrates used in the experiment in Belg and Maher season at Abelo area masha district south west Ethiopia

\section{Cattle manure(CM)}

\section{Parameters}

$\mathrm{pH}$

Electrical conductivity (us $\mathrm{cm}_{-}{ }^{1}$ )

Organic carbon $\left(\mathrm{g} \mathrm{kg}^{-1}\right)$

Total $\mathrm{N}\left(\mathrm{g} \mathrm{kg}^{-1}\right)$

C: $\mathrm{N}$

Total phosphorous $\mathrm{P}_{2} \mathrm{O}_{5}(\%)$

Total $\mathrm{CaO}$ cmol (+) $\mathrm{kg}^{-1}$

Total Mg Mg Ocmol (+) kg-

Total K K2O cmol (+) kg- ${ }^{1}$

Total Na cmol (+) $\mathrm{kg}^{-1}$

CEC ( $\mathrm{cmol}(+) \mathrm{kg}^{-1}$

Moisture content (\%)

\section{Belg (short rain season-February to May)}

6.8
182
25
1.92
$01: 13.0$
1.374
7.854
1.33
4.674
0.07
38
78

Maher (long rain season-June to October)

7.1
148
22
1.6
$1 ; 13.75$
1.19
6.748
0.99
5.22
0.09
32
81

Table 4: Days to 50\% flowering (D50\%), days to 50\% maturity (Dm) and Average plant height (cm) of potato as influenced by the combined use of farmyard manure and mineral NP fertilizers in Belg and Meher season, at abelo area Masha district sheka zone southwestern Ethiopia

\begin{tabular}{|c|c|c|c|c|c|c|}
\hline \multirow[t]{2}{*}{ Treatment* } & \multicolumn{3}{|c|}{2016 Belgseason } & \multicolumn{2}{|c|}{2016 Meherseason } & \multirow[b]{2}{*}{$\begin{array}{c}\text { Average plant } \\
\text { height (cm) }\end{array}$} \\
\hline & $\begin{array}{c}\text { Days to } 50 \% \\
\text { flowering }\end{array}$ & $\begin{array}{c}\text { Days to } 50 \% \\
\text { maturity }\end{array}$ & $\begin{array}{l}\text { Average plant } \\
\text { height (cm) }\end{array}$ & $\begin{array}{c}\text { Days to } 50 \% \\
\text { flowering }\end{array}$ & $\begin{array}{c}\text { Days to } 50 \% \\
\text { maturity }\end{array}$ & \\
\hline $\mathrm{T}_{3}$ & $56^{\mathrm{cd}}$ & $102.33^{\text {de }}$ & $60 .^{\text {de }}$ & $55.66^{g}$ & $99.33^{\mathrm{fg}}$ & $68.03^{\mathrm{fg}}$ \\
\hline $\mathrm{T}_{4}$ & $56^{\mathrm{cd}}$ & $102.67^{\text {cde }}$ & $61.3^{\mathrm{de}}$ & $57.00^{g f}$ & $100.67^{\text {ef }}$ & $69^{e f}$ \\
\hline $\mathrm{T}_{5}$ & $57^{\mathrm{cd}}$ & $103^{\text {bcde }}$ & $61.967^{\mathrm{cd}}$ & $58.00^{\text {ef }}$ & $102.00^{\text {de }}$ & $70^{\text {def }}$ \\
\hline $\mathrm{T}_{6}$ & $58.66^{c}$ & $103.33^{\text {abcde }}$ & $63.633^{\mathrm{bcd}}$ & $58.66 d^{\text {ef }}$ & $102.67^{\mathrm{de}}$ & $71.33^{\text {cde }}$ \\
\hline $\mathrm{T}_{7}$ & $57.33^{\mathrm{bcd}}$ & $104.67^{\mathrm{abcd}}$ & $63.70^{\mathrm{bcd}}$ & $59.66^{\text {cde }}$ & $103.67^{\mathrm{dc}}$ & $72.07^{\mathrm{dc}}$ \\
\hline $\mathrm{T}_{8}$. & $58.33^{\text {abcd }}$ & $105^{\mathrm{a}}$ & $65.63^{\mathrm{abc}}$ & $60.33^{\text {cd }}$ & $105.00^{\mathrm{bc}}$ & $73^{c}$ \\
\hline $\mathrm{T}_{9}$ & $60^{\mathrm{abc}}$ & $105.33^{\mathrm{ab}}$ & $65.87^{\mathrm{ab}}$ & $61.33^{\mathrm{bc}}$ & $106.33^{\text {ba }}$ & $73.9^{\mathrm{bc}}$ \\
\hline $\mathrm{T}_{10}$ & $61^{\mathrm{ab}}$ & $105.67^{\mathrm{a}}$ & $68.3^{\mathrm{a}}$ & $62.66^{b}$ & $107.67^{\mathrm{a}}$ & $76.33^{\mathrm{ab}}$ \\
\hline $\mathrm{T}_{11}$ & $63^{\mathrm{a}}$ & $105.67^{\mathrm{a}}$ & $69.33^{\mathrm{a}}$ & $65.00^{\mathrm{a}}$ & $108.33^{\mathrm{a}}$ & $78.67^{\mathrm{a}}$ \\
\hline $\mathrm{T}_{2}$ & $55.33^{\text {cd }}$ & $102.33^{\text {de }}$ & $57.97^{\mathrm{ef}}$ & $55.33^{\mathrm{g}}$ & $97.67^{\mathrm{g}}$ & $65.67^{\text {gh }}$ \\
\hline $\mathrm{T}_{1}$ & $51^{\mathrm{d}}$ & $101^{\mathrm{e}}$ & $55.967^{\mathrm{f}}$ & $51.00^{\mathrm{h}}$ & $95.33^{\mathrm{h}}$ & $63.33^{\mathrm{h}}$ \\
\hline LSD (5 \%) & 4.97 & 2.48 & 3.79 & 2.3232 & 2.32 & 2.34 \\
\hline Sig & $* *$ & $* *$ & $* *$ & $* *$ & $* *$ & $* *$ \\
\hline CV $(\%)$ & 5.051 & 1.4 & 3.53 & 1.85 & 1.33 & 2.34 \\
\hline
\end{tabular}




\section{Days to $\mathbf{5 0 \%}$ flowering}

Application of $7.5 \mathrm{t} \mathrm{CM}+75 \% \mathrm{RDF}$ delayed the time required to reach $50 \%$ flowering from $56-63$ by 7 days and 51-65 days 14 days which is Statistical at par with T10, T9 and T8 in Belg season (Table 2.5). This is because high dosage cattle manure with mineral NP levels promoted excessive vegetative growth and delayed flowering. both in Belg and Meher season while the earliest time to flowering was recorded at control both in Belg and Meher season which is Statistical the same as T2, T3, T4 and T5 in Belg season and T10 and T9 in Meher season. This could be cattle, manure combined with mineral NP can result in the improvement of soil characteristics (physical and biological) this in turn increases nutrient availability encourage vegetative growth there by photsynsty is This result is similar with the findings of $[35,36]$ they reported excessive vegetative growth and delayed flowering due to high nutrient dosage levels, in addition, [37] reported that the application of $\mathrm{N}$ and P fertilizers delayed the time required to attain flowering of potato.

It was observed at both seasons days to $50 \%$ flowering delayed when organic fertilizer sources were combined with the highest rate $(75 \%)$ of the recommended mineral NP. but the delay is higher in Meher season

\section{Days to $50 \%$ maturity (Dm)}

Increasing the application dosage of cattle manure with Mineral NP resulted in delaying the time to reach 50\% maturity by 5 days from (101-106) and 13 days from (95-108) which is Statistical the same as T10, T9, T8, T7and T6 in Belg season (Table 2.5). This is due to the fact that increased level of combined use of Cattle Manure with mineral NP increased significant role in crop establishment, promoting vegetative growth, and there by the leaf area which in turn increased the amount of solar radiation intercepted and subsequently delays days to $50 \%$ physiological maturity

The earliest time attained for $50 \%$ maturity was at zero application of cattle manure and mineral NP which is Statistical the same as T2, T3, T4, T5 and T6 in Belg season

The observation of the present investigation supports the earlier studies on the effect of combined use of cattle manure on days to $50 \%$ maturity $[38,39]$ where increased combined use of cattle manure with increased mineral NP was reported to be related to delaying maturity of potato. In both seasons days to $50 \%$ maturity delayed when cattle manure was combined with the highest rate $(75 \%)$ of the recommended mineral NP. but the delay to rech $50 \%$ maturity is higher in Meher season

\section{Plant height (Ph) (cm)}

The highest plant height of potato $(69.33$ and $78.66 \mathrm{~cm}$ ) in Belgand Meher season was obtained at combined application of $7.5 \mathrm{t} \mathrm{CM}$ with 75\% RDF which is Statistical at par with T10,T9 and T8 in Belg season and T10 in Meher season, application of 7.5 t CM with 75\% RDF, increases plant height from 56-69 and 51$65 \mathrm{~cm}$ in Belgand Meher season respectively while the shortest plants were from the control treatment where no mineral NP and cattle manure is applied both in Belgand Meher season respectively(Table 4).

It was observed at both season plant height increased when cattle manure was combined with the highest rate $(75 \%)$ of the recommended mineral NP. but the increment in height is higher in Meher season this is in lined with work of $[40,41]$.

The possible reason for higher plant height in increase rate of CM plus mineral NP treatment might be due to the fact that the cattle macronutrret combine with mineral fertilizer would have provided the micronutrients in an optimum range for the plant This increases the better efficiency of mineral NP fertilizer the mineral NP sources fulfilled the NP requirements at early growth stages while cattle manure provided the crop with nutrients in later stages due to their slow releasing nature.

The result of this experiment was in agreement with the finding of they reported that $t$ the highest values of plant height, stem diameter and leaf size were detected with plants which were fertilized with cow dung at the rate of $20 \mathrm{t} \mathrm{ha}^{-1}$. and NPK at the rate of (20: 10: 10) compared with sole application of cow dung or NPK mineral fertilize the shortest plants height were recorded from the control treatment [42].which is Statistical the same as T2 in both Belg and Meher season

Similarly, reported that plant height of potato increased with organic manure application as compared to mineral fertilizer alone. $[43,44]$ also reported that the use of organic manures in combination with mineral fertilizers increased the plant height of potato than the application of mineral fertilizers alone.

\section{Potato tuber size categories}

The percentage of small and medium-sized tubers were highly significantly $(\mathrm{P}<0.01)$ affected by combining the use of Cattle Manure and mineral NP fertilizer, but Percentage of large tuber size was non-significantly $(\mathrm{P}>0.05)$ affected by combining the use of cattle manure and mineral NP fertilizers in both in Belg and Meher seasons (Table 5).

\section{Small tuber size number (\%)}

Significantly the highest percentage of small-sized tubers (27.36 and $27.306 \%$ ) were obtained at no application of cattle manure and mineral NP, and the average small sized tuber percentage (22.14 and27. 07\%) whereas the lowest percentage of small potato tubers (17.06 and14. 26\%) were found at $7.5 \mathrm{t}$ $\mathrm{CM}+75 \% \mathrm{RDF}$, (Table 5). This might be at low nutrient dosage there could be weak competition for light, water, and nutrients from their sources and this reduced photoassimilate production and redistribution to the tubers and finally, the highest number of small-sized tubers produced.)[45] also concluded that in a low nutrient dosage bulking rate of individual tubers decreased, and these resulted in the higher proportion smaller size tuber. (Biruke et, al. 2015) reported that the number of small-sized tubers was reduced by increasing the nutrient dosage. 
The Effects of Combined Application of Cattle manure And Mineral Nitrogen And Phosphorus Fertilizer on Growth, Biomass Yield, And Quality of Potato (Solanum Tuberosum L) Tuber In abelo Area at Masha District sheka Zone, South-Western Ethiopia

Table 5: Means for tuber size category (small, medium, and large) of potato as affected by combining use of cattle manure and mineral NP in Belgand Meher season at abelo area Masha district sheka zone southwestern Ethiopia

\begin{tabular}{|c|c|c|c|c|c|c|}
\hline \multirow[t]{2}{*}{ Treatment* } & \multicolumn{3}{|c|}{ Number of tubers 2016 Belgseason } & \multicolumn{3}{|c|}{ Number of tubers 2016 meherseason } \\
\hline & $\begin{array}{l}\text { Large size tuber } \\
\quad(>75 \mathrm{~g})\end{array}$ & $\begin{array}{c}\text { Medium } \\
\text { Size tuber(75-39g) }\end{array}$ & $\begin{array}{c}\text { Small } \\
\text { Size Tuber }(<39 g)\end{array}$ & $\begin{array}{l}\text { Large size tuber } \\
\qquad(>75 g)\end{array}$ & $\begin{array}{c}\text { Medium } \\
\text { Size tuber(75-39g) }\end{array}$ & $\begin{array}{c}\text { Small SizeTuber } \\
(<39 \mathrm{~g})\end{array}$ \\
\hline $\mathrm{T}_{3}$ & 6.175 & $67.185^{\mathrm{gh}}$ & $26.640^{\mathrm{ab}}$ & 8.724 & $54.394^{\text {def }}$ & $36.882^{\mathrm{a}}$ \\
\hline $\mathrm{T}_{4}$ & 8.257 & $67.654^{\mathrm{fgh}}$ & $24.089^{\mathrm{bc}}$ & 9.715 & $56.621^{\mathrm{de}}$ & $33.664^{\mathrm{abc}}$ \\
\hline $\mathrm{T}_{5}$ & 8.651 & $68.916^{\mathrm{efg}}$ & $22.433^{\text {cd }}$ & 10.218 & $63.217^{\mathrm{cd}}$ & $26.565^{\mathrm{bcd}}$ \\
\hline $\mathrm{T}_{6}$ & 7.852 & $69.962^{\text {def }}$ & $22.186^{\text {cde }}$ & 8.255 & $68.372^{\mathrm{bc}}$ & $23.373^{\text {cd }}$ \\
\hline $\mathrm{T}_{7}$ & 8.815 & $70.943^{\text {cde }}$ & $20.242^{\text {def }}$ & 4.923 & $73.021^{\mathrm{ab}}$ & $22.056^{\mathrm{cd}}$ \\
\hline $\mathrm{T}_{8}$. & 8.714 & $71.895^{\mathrm{bcd}}$ & $19.391^{\text {def }}$ & 4.604 & $75.700^{\mathrm{ab}}$ & $19.696^{d}$ \\
\hline $\mathrm{T}_{9}$ & 7.809 & $73.266^{\mathrm{abc}}$ & $18.925^{\mathrm{ef}}$ & 5.313 & $76.865^{\mathrm{ab}}$ & $17.822^{\mathrm{d}}$ \\
\hline $\mathrm{T}_{10}$ & 8.204 & $74.070^{\mathrm{ab}}$ & $17.726^{\mathrm{f}}$ & 3.621 & $79.147^{\mathrm{ab}}$ & $17.232^{\mathrm{d}}$ \\
\hline $\mathrm{T}_{11}$ & 8.145 & $74.786^{\mathrm{a}}$ & $17.069^{\mathrm{f}}$ & 5.471 & $80.260^{\mathrm{a}}$ & $14.269^{\mathrm{d}}$ \\
\hline $\mathrm{T}_{2}$ & 6.451 & $65.932^{\mathrm{h}}$ & $27.617^{a}$ & 8.578 & $49.149^{e f}$ & $42.273^{\mathrm{a}}$ \\
\hline $\mathrm{T}_{1}$ & 7.135 & $65.559^{h}$ & $27.306 a$ & 11.472 & $44.582^{\mathrm{f}}$ & $43.946^{a}$ \\
\hline $\operatorname{LSD}(5 \%)$ & 2.73 & 2.729 & 3.402 & 2.65 & 11.356 & 12.511 \\
\hline Sig & NS & ** & ** & Ns & ** & ** \\
\hline CV (\%) & 23.21 & 2.28 & 9.02 & 23.76 & 10.168 & 27.13 \\
\hline
\end{tabular}

Means followed by the same letter within a column are not significantly different at $\mathrm{P}>0.05$ level of significance; ${ }^{*} \mathrm{CM}=\mathrm{Cattle}$ Manurein $\mathrm{tha}-1, \mathrm{RDF}$ $=$ Recommended Dose of mineral NP Fertilizer,

$\mathrm{T} 1=$ Control, $\mathrm{T} 2=100 \% \mathrm{RDF}, \mathrm{T} 3=2.5 \mathrm{t} \mathrm{CM}+25 \% \mathrm{RDF}, \mathrm{T} 4=2.5 \mathrm{tCM}+50 \% \mathrm{RDF}, \mathrm{T} 5 .=2.5 \mathrm{tCM}+75 \% \mathrm{RDF}, \mathrm{T} 6 .=5 \mathrm{t} \mathrm{CM}+25 \% \mathrm{RDF}, \mathrm{T} 7=5 \mathrm{t} \mathrm{CM}+50 \% \mathrm{RDF}, \mathrm{T} 8$. $=5 \mathrm{t} \mathrm{CM}+75 \% \mathrm{RDF}, \mathrm{T} 9=7.5 \mathrm{t} \mathrm{CM}+25 \% \mathrm{RDF}, \mathrm{T} 10=7.5 \mathrm{t} \mathrm{CM}+50 \% \mathrm{RDF}$, T11=7.5 t CM+75\% RDF, RDF = Recommended Dose of mineral NP Fertilizer, $\mathrm{CM}=$ Cattle Manurein $\mathrm{t} \mathrm{ha}^{-1}$

It was observed at both season, that the proportion of Small tuber size number decreased when cattle manure were combined with the highest rate (75\%) of the recommended mineral NP. But the decrease in proportion of small tuber size is higher in Meher season than in Belg season

\section{Medium tuber size number (\%)}

The medium tuber size number ranged from $(65.56$ and44.58\%) (zero application of Cattle manure and mineral NP) to74.78and 80.26percentagein Belgand Meher season respectively. The maximum mean medium tuber size number obtained with the combined application of $7.5 \mathrm{tCM}+75 \% \mathrm{RDF}$ had no significant difference with (T10)7.5tCM+50\% RDF (T9) $7.5 \mathrm{tCM}+25 \% \mathrm{RDF}$ in Belg season and (T10)7.5tCM+50\% RDF, (T9) $7.5 \mathrm{tCM}+25 \%$ RDF, 5tCM+75\% RDF, (T8) 5tCM+50\% RDF in Meher season and the lowest proportion of medium size tubers(65.559) in Belg season and (44.582) in Meher season was obtained at zero application of cattle manure and minral NP which is stasticalley the same as application of $\mathrm{T} 2, \mathrm{~T} 3$, and $\mathrm{T} 4 \mathrm{in}$ Belg season and T2, and T3 in Meher season (Table 5).

It was indicated at, that the proportion of Medium tuber size number increased when cattle manure was combined with the highest rate $(75 \%)$ of the recommended mineral NP. both in Belgand Meher seasons but the increase in the proportion of
Medium tuber size number is higher in Meher season than in Belg season similarly combined the use of 5.0 tha $^{-1} \mathrm{Cm}+50 \%$ RDF improved medium size potato tuber from zero application (53.29) to $62.88 \%$ at Jimma Arjo Ethiopia [46].

Significantly the highest percentage of medium-sized potato tubers (74.7 and80.26\%) were recorded at the application of $7.5 \mathrm{tCM}+75 \%$ RDF but the lowest percentage (65.56 and 44.58) were obtained at zero application of cattle manure and mineral NP in both Belgand Meher seasons (Table 2.6).

\section{Biomass Yield Parameters}

\section{Shoot fresh and Dry biomass yield}

Shoot fresh and dry weight were highly significant $(\mathrm{P}<0.01)$ affected by combining the use of cattle manure and mineral NP in both Belg and Meher season (Table 6).

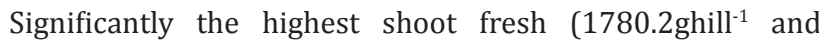
1658.99 ghill $^{-1}$ ) and dry (59.333 ghill-1and56.667 ghill $^{-1}$ ) weight was recorded at the higher dosage level of $7.5 \mathrm{t} \mathrm{CM+75 \%} \mathrm{RDF}$ whereas the lowest shoot fresh Wight (1274.59ghill-1 and 1213.91 ghill $^{-1}$ ) and dry weight $\left(40.4\right.$ ghill $^{-1}$ and 40 ghill $^{-1}$ ) in Belg and Meher season were obtained at zero application of cattle manure and mineral NP and the mean average shoot

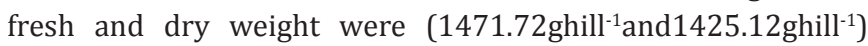


in Belg, 47.78ghill ${ }^{-1}$,and47.9ghill ${ }^{-1}$ ) recorded in Belgand Meher season respectively(Table 2.7). This might be in the higher nutrient dosage there could also lead to better plant coverage for a high radiation interception, optimum foliage development subsequently increased the photosynthetic efficiency of the plant and finally resulting in increased shoot fresh weight. Appropriate use of nitrogen fertilizer can lead to the accomplishment of optimum foliage development and consequently promotes tuber yield.

Similar to the result of the current investigation Ahmed [47] also reported that maximum above ground fresh and dry biomass yield of tubers per plant was obtained with the combined use of 20 tha $^{-1}$ cattle manure with different mineral nitrogen fertilizer. In a similar manner,[48] also indicated that combined use of Nitrogen and Phosphorous gave the highest above ground fresh and dry biomass yield number of tubers per hill. In addition, [49] also reported that shoot fresh and dry weight of potatoper hill increased at the higher rate of cattle manure Nitrogen and phosphorous

It was indicated at, that Shoot fresh and Dry biomass yield increased when cattle manure was combined with the highest rate $(75 \%)$ of the recommended mineral NP.both in Belg and Meher seasons but the increment is higher in Belg season than in Meher season
The mean values of the Shoot fresh weight, shoot dry weight ( ghill- $^{-1}$ ) of the soil is also presented in Table 6As can be seen from the Table 2.7, regardless of the chemical fertilizer, the biomass yield of potato increased with the added rate of cattle manure the highest and lowest biomass yield of potato of each of these nutrients was recorded for plots treated with $7.5 \mathrm{t} \mathrm{CM}+75 \% \mathrm{RDF}$ and those which did not receive cattle manure and mineral NP at any rate, respectively. several searchers $[50,51,52]$ who reported the significant increase biomass yield of potato after cattle manure and Mineral NP application support the finding of the present study

According to the current investigation the results obtained in terms of the following biomass yield parameters such as shoot fresh weight, shoot dry weight, root, fresh weight, root dry weight, and harvest index in Belg and Mehre season were presented (Table 6) and discussed as follows

\section{Root, fresh and Dry biomass yield}

Root, fresh and dry biomass yield were significantly $(P<$ 0.01) influenced by the combined application of cattle manure and mineral NP both in Belge and Meher season (Table 6). Accordingly, the application of $7.5 \mathrm{t} \mathrm{ha}^{-1} \mathrm{CM}$ in combination with $75 \%$ mineralNP gave the highest root, fresh and dry biomass yield of (177.394 and 171.55g hill ${ }^{-1}$.)In Belge and (9.343 and 9.594g hill $^{-1}$.) in Mehre, season which is Statistical at par with T10, T9 in

Table 6: Means for shoot fresh weight, and shoot dry weight of potato as affected by combining use of cattle manure and mineral NP Belg and Maher season at Abelo area Masha district sheka zone southwestern Ethiopia

\begin{tabular}{|c|c|c|c|c|}
\hline \multirow[t]{2}{*}{ Treatment* } & \multicolumn{2}{|c|}{2016 Belgseason } & \multicolumn{2}{|c|}{ 2016Meher season } \\
\hline & $\begin{array}{l}\text { Shoot fresh weight } \\
\text { g hill }^{-1} \text {. }\end{array}$ & $\begin{array}{c}\text { Shoot dry weight } \\
\text { g hill }{ }^{-1} \text {. }\end{array}$ & $\begin{array}{c}\text { Shoot } \\
\text { fresh weight } \\
\text { g hill }^{-1} \text {. }\end{array}$ & $\begin{array}{c}\text { Shoot dry weight } \\
\text { g per } \\
\text { hill- }^{-1} .\end{array}$ \\
\hline $\mathrm{T}_{3}$ & $1292.40^{\mathrm{g}}$ & $41.067^{\mathrm{g}}$ & $1302.93^{\mathrm{fg}}$ & $43.333^{\mathrm{fg}}$ \\
\hline $\mathrm{T}_{4}$ & $1310.20^{\mathrm{fg}}$ & $41.733^{\mathrm{fg}}$ & $1320.73^{\mathrm{fg}}$ & $44.000^{\mathrm{fg}}$ \\
\hline $\mathrm{T}_{5}$ & $1354.71^{\mathrm{f}}$ & $43.400^{f}$ & $1365.24^{\mathrm{ef}}$ & $45.667^{\mathrm{ef}}$ \\
\hline $\mathrm{T}_{6}$ & $1434.82^{\mathrm{e}}$ & $46.400^{f}$ & $1400.85^{\mathrm{de}}$ & $47.000^{\mathrm{de}}$ \\
\hline $\mathrm{T}_{7}$ & $1497.13^{\mathrm{d}}$ & $48.733^{\mathrm{d}}$ & $1436.45^{\text {cd }}$ & $48.333^{\text {cd }}$ \\
\hline $\mathrm{T}_{8 .}$ & $1559.45^{c}$ & $51.067^{c}$ & $1498.76^{c}$ & $50.667^{c}$ \\
\hline $\mathrm{T}_{9}$ & $1648.46^{b}$ & $54.400^{\mathrm{b}}$ & $1569.98^{\mathrm{b}}$ & $53.333^{\mathrm{b}}$ \\
\hline $\mathrm{T}_{10}$ & $1753.50^{\mathrm{a}}$ & $58.333^{\mathrm{a}}$ & $1650.09^{\mathrm{a}}$ & $56.333^{\mathrm{a}}$ \\
\hline $\mathrm{T}_{11}$ & $1780.21^{\mathrm{a}}$ & $59.333^{\mathrm{a}}$ & $1658.99^{a}$ & $56.667^{\mathrm{a}}$ \\
\hline $\mathrm{T}_{2}$ & $1283.49^{g}$ & $40.733^{g}$ & $1258.42^{\text {gh }}$ & $41.667^{\mathrm{gh}}$ \\
\hline $\mathrm{T}_{1}$ & $1274.59^{\mathrm{g}}$ & $40.4^{g}$ & $1213.91^{\mathrm{h}}$ & $40 \mathrm{~h}$ \\
\hline LSD (5 \%) & 2.086 & 2.28 & 69.57 & 2.6 \\
\hline Sig & $* *$ & $* *$ & $* *$ & $* *$ \\
\hline CV (\%) & 2.42 & 2.8 & 2.86 & 3.19 \\
\hline
\end{tabular}

Means followed by the same letter within a column are not significantly different at $\mathrm{P}>0.05$ level of significance; ${ }^{\mathrm{CM}}=\mathrm{Cattle}$ Manurein $\mathrm{t}$ ha-1, $\mathrm{RDF}$ $=$ Recommended Dose of mineral NP Fertilizer, $\mathrm{T} 1=$ Control, $\mathrm{T} 2=100 \% \mathrm{RDF}, \mathrm{T} 3=2.5 \mathrm{t} \mathrm{CM}+25 \% \mathrm{RDF}, \mathrm{T} 4=2.5 \mathrm{tCM}+50 \% \mathrm{RDF}, \mathrm{T} 5 .=2.5 \mathrm{tCM}+75 \% \mathrm{RDF}$, T6. $=5$ t CM+25\% RDF, T7=5 t CM+50\% RDF, T8. $=5$ t CM+75\% RDF, T9=7.5 t CM+25\% RDF, T10=7.5 t CM+50\% RDF, T11=7.5 t CM+75\% RDF,RDF = Recommended Dose of mineral NP Fertilizer, $\mathrm{CM}=$ Cattle Manurein $\mathrm{t}_{\mathrm{h}} \mathrm{H}^{-1}$ 
Belg T10, T9, T8 in Meher season for fresh and dry root biomass yield whereas the lowest fresh root biomass yield (133.19 and 99.18g hill ${ }^{-1}$.) and dry root biomass yield (6.676and 5.23g hill-1.) in Belg and Meher season was recorded at zero application of cattle manure and mineral NP which is stasticalley the same as T2, T3, T4 for root fresh biomass yield in Belg and Meher season $\mathrm{T} 2, \mathrm{~T} 3, \mathrm{~T} 4, \mathrm{~T} 5, \mathrm{~T} 6$ for root fresh and dry weight in Meher season. (Table 6).

Generally, the combined application of cattlemanure and mineral NP fertilizers have resulted in a higher fresh and dry underground biomass yield than the application of $100 \%$ recommended arate of mineralNP alone. This implies that in the study area the integrated use of cattlemanure and mineral NP fertilizers responded better to increase productivity than the use of mineralfertilizer alone Likewise, suggested that Farmers who use ISFM technology at low applicationrates may not see yield differences from a sole inputapplication in a combined application. Application of mineral fertilizer alone led to yields equivalent to control yields, regardless of application rate[53].

It was indicated that Root, fresh and Dry biomass yield increased when cattle manure was combined with the highest rate $(75 \%)$ of the recommended mineral NP. both in Belgand Meher seasons but the increment is higher in Belgs eason than in Meher season

by the use of mixed mineral and cattle manure fertilizers not only production can be kept at an optimum level, but also the amount of mineral fertilizer to be used can be reduced. Plant biochemical activities improve by absorption of nutrients from the soil and this, in turn,increases biomass yield plant ${ }^{-1}[54]$.

Table 7: Root fresh weight, root dry weight and harvest index of potato as influenced by combined use of cattle manure and mineral fertilizers at Masha in Belg and Maher season at abelo area Masha district sheka zone southwestern Ethiopia

\begin{tabular}{|c|c|c|c|c|c|c|}
\hline \multirow[t]{2}{*}{ Treatment* } & \multicolumn{3}{|c|}{2016 Belg season } & \multicolumn{3}{|c|}{2016 Mehreseason } \\
\hline & Root fresh weight g per hill. & $\begin{array}{l}\text { Root dry weight g } \\
\text { per hill. }\end{array}$ & $\begin{array}{c}\text { Harvest index } \\
\text { (\%) }\end{array}$ & $\begin{array}{c}\text { Root fresh weight g } \\
\text { per hill. }\end{array}$ & $\begin{array}{c}\text { Root dry weight g } \\
\text { per hill. }\end{array}$ & $\begin{array}{c}\text { Harvest } \\
\text { index (\%) }\end{array}$ \\
\hline $\mathrm{T}_{3}$ & $139.15^{\text {ef }}$ & $7.04^{\mathrm{ef}}$ & 0.8 & $111.44^{\mathrm{e}}$ & $5.96^{\mathrm{de}}$ & 0.723 \\
\hline $\mathrm{T}_{4}$ & $141.92^{\mathrm{def}}$ & $7.20^{\text {def }}$ & 0.8 & $114.81^{\mathrm{de}}$ & $6.17^{\mathrm{de}}$ & 0.738 \\
\hline $\mathrm{T}_{5}$ & $152.02^{\text {cde }}$ & $7.81^{\text {cde }}$ & 0.78 & $125.91^{\text {cde }}$ & $6.84^{\text {cde }}$ & 0.733 \\
\hline $\mathrm{T}_{6}$ & $154.40^{\text {bcd }}$ & $7.96^{\text {bcd }}$ & 0.78 & $129.78^{\text {bcde }}$ & $7.07^{\text {bcde }}$ & 0.727 \\
\hline $\mathrm{T}_{7}$ & $155.39^{\mathrm{bc}}$ & $8.02^{\mathrm{bc}}$ & 0.759 & $136.29^{\mathrm{bcd}}$ & $7.46^{\mathrm{bcd}}$ & 0.721 \\
\hline $\mathrm{T}_{8}$ & $159.26^{\mathrm{bc}}$ & $8.25^{\mathrm{bc}}$ & 0.753 & $146.73^{\mathrm{abc}}$ & $8.09^{\mathrm{abc}}$ & 0.711 \\
\hline $\mathrm{T}_{9}$ & $166.92^{\mathrm{ab}}$ & $8.71^{\mathrm{ab}}$ & 0.741 & $157.5^{4 a b}$ & $8.75^{\mathrm{ab}}$ & 0.706 \\
\hline $\mathrm{T}_{10}$ & $175.79^{\mathrm{a}}$ & $9.24^{\mathrm{a}}$ & 0.736 & $167.41 \mathrm{a}$ & $9.34^{\mathrm{a}}$ & 0.704 \\
\hline $\mathrm{T}_{11}$ & $177.39^{\mathrm{a}}$ & $9.34^{\mathrm{a}}$ & 0.728 & $171.55^{\mathrm{a}}$ & $9.59^{\mathrm{a}}$ & 0.705 \\
\hline $\mathrm{T}_{2}$ & $134.3^{\mathrm{f}}$ & $6.74^{\mathrm{f}}$ & 0.834 & $104.04^{\mathrm{e}}$ & $5.52^{\mathrm{e}}$ & 0.733 \\
\hline $\mathrm{T}_{1}$ & $133.19^{f}$ & $6.676^{f}$ & 0.868 & $99.18^{\mathrm{e}}$ & $5.23^{e}$ & 0.735 \\
\hline LSD (5 \%) & 13.18 & 0.7957 & 5.28 & 30.75 & 1.86 & 0.036 \\
\hline Sig & $* *$ & $* *$ & Ns & $* *$ & $* *$ & Ns \\
\hline $\mathrm{CV}(\%)$ & 5.04 & 5.9 & 8.41 & 13.56 & 14.97 & 2.97 \\
\hline
\end{tabular}

Means followed by the same letter within a column are not significantly different at $\mathrm{P}>0.05$ level of significance; $* \mathrm{CM}=\mathrm{Cattle}$ Manurein $\mathrm{t}$ ha- 1 , RDF $=$ Recommended Dose of mineral NP Fertilizer, T1 $=$ Control, $\mathrm{T} 2=100 \% \mathrm{RDF}, \mathrm{T} 3=2.5 \mathrm{t} \mathrm{CM}+25 \% \mathrm{RDF}, \mathrm{T} 4=2.5 \mathrm{tCM}+50 \% \mathrm{RDF}, \mathrm{T} 5 .=2.5 \mathrm{tCM}+75 \% \mathrm{RDF}, \mathrm{T} 6 .=5 \mathrm{t} \mathrm{CM}+25 \%$

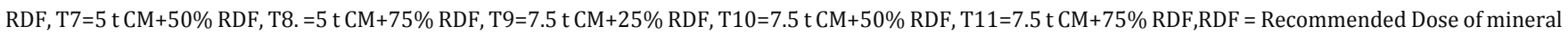
NP Fertilizer, $\mathrm{CM}=$ Cattle Manurein $\mathrm{tha}^{-1}$

\section{Quality Parameters}

\section{Dry matter content and specific gravity}

Also, there was significant $(\mathrm{P}<0.01)$ effect of combined application of o faryared manure and mineral NP on specific gravity $\mathrm{gcm}^{-3}$ and dry matter content inboth in Belge and Meher season (Table 8). It was observed that the combined application of farmyard manureand mineral NP fertilizers reduced specific gravity $\mathrm{gcm}^{-3}$ and drymatter contentpercent both in Belge and Meher season.
As a result, the application of $7.5 \mathrm{t} \mathrm{ha}^{-1}$ cattle manure with $75 \%$ mineral NP resulted in the highest specific gravity of (1.107 and $1.111 \mathrm{gcm}^{-3}$ ) and dry matter content percentage of (25.78 and 24.47) in Belgand Meher season, respectively. This treatment gave $2.23 \%$ and $2.19 \%$ improvement of specific gravity in $\mathrm{gcm}^{-3}$ over the control treatment in Belge and Meher season respectively (Table 8). This might be due to the increased rate of $\mathrm{CM}$ which might have attributed to the increased availability of NPK, improvement of soil, water holding capacity, and reduction of volatilization of nitrogenous fertilizer to NH3 gas. Similarly, 
reported $m$ the maximum specific gravity (1.07) was recorded in (CM) in combination with mineral Nitrogen [55].

It was also observed that as the rate of mineral NP increased from 25 to $75 \%$, there was an increase in the number of dry matter content both in Belge and Meher. season the improvement in a proportion of dry matter content at higher NP rates might be due to vigorous growth and development of the crop because

Table 8: Dry matter content, and Specific gravity of potato as influenced by combined use mineral NP and cattle manure in Belg and Meher season, at abelo area Masha district sheka zone southwestern Ethiopia

\begin{tabular}{|c|c|c|c|c|}
\hline \multirow[t]{2}{*}{ Treatment* } & \multirow[b]{2}{*}{$\begin{array}{c}\text { Specific gravity } \\
\left(\mathrm{gcm}^{-3}\right)\end{array}$} & \multirow{2}{*}{$\begin{array}{c}2016 \text { Belgseason } \\
\text { Dry matter content (\%) }\end{array}$} & \multicolumn{2}{|c|}{ Meher Season } \\
\hline & & & $\begin{array}{l}\text { Specific gravity } \\
\qquad\left(\mathrm{gcm}^{-3}\right)\end{array}$ & $\begin{array}{c}\text { Dry matter content } \\
(\%)\end{array}$ \\
\hline $\mathrm{T}_{3}$ & $1.089^{\mathrm{ef}}$ & $21.906^{\mathrm{efg}}$ & $1.092^{\mathrm{de}}$ & $22.571^{\mathrm{de}}$ \\
\hline $\mathrm{T}_{4}$ & $1.090^{\mathrm{ef}}$ & $22.121^{\mathrm{ef}}$ & $1.092^{\mathrm{de}}$ & $22.599^{\mathrm{de}}$ \\
\hline $\mathrm{T}_{5}$ & $1.091^{\mathrm{de}}$ & $22.38^{e}$ & $1.092^{\mathrm{de}}$ & $22.641^{\mathrm{de}}$ \\
\hline $\mathrm{T}_{6}$ & $1.092^{\text {cde }}$ & $22.718^{\mathrm{de}}$ & $1.093^{\text {cde }}$ & $22.768^{\text {cde }}$ \\
\hline $\mathrm{T}_{7}$ & $1.095^{\mathrm{cd}}$ & $23.303^{\text {cd }}$ & $1.095^{\mathrm{bcd}}$ & $23.274^{\text {bcd }}$ \\
\hline $\mathrm{T}_{8 .}$ & $1.095^{\mathrm{cd}}$ & $23.349^{\mathrm{cd}}$ & $1.097^{\mathrm{bc}}$ & $23.563^{\mathrm{bc}}$ \\
\hline $\mathrm{T}_{9}$ & $1.097^{\mathrm{bc}}$ & $23.687^{c}$ & $1.098^{\mathrm{ab}}$ & $23.837^{\mathrm{ab}}$ \\
\hline $\mathrm{T}_{10}$ & $1.101 \mathrm{~b}$ & $24.527^{\mathrm{b}}$ & $1.099^{\mathrm{ab}}$ & $23.935^{\mathrm{ab}}$ \\
\hline $\mathrm{T}_{11}$ & $1.107^{\mathrm{a}}$ & $25.782^{\mathrm{a}}$ & $1.101^{\mathrm{a}}$ & $24.470^{\mathrm{a}}$ \\
\hline $\mathrm{T}_{2}$ & $1.086^{\mathrm{fg}}$ & $21.325 \mathrm{f}^{\mathrm{g}}$ & $1.091^{\mathrm{e}}$ & $22.473^{\mathrm{de}}$ \\
\hline $\mathrm{T}_{1}$ & $1.083^{\mathrm{g}}$ & $21.085^{\mathrm{g}}$ & $1.092^{\mathrm{de}}$ & $22.360^{\mathrm{e}}$ \\
\hline LSD (5 \%) & 0.0047 & 0.83 & 0.0042 & 0.8923 \\
\hline Sig & $* *$ & $* *$ & $* *$ & $* *$ \\
\hline CV (\%) & 0.25 & 2.12 & 0.23 & 2.26 \\
\hline
\end{tabular}

Values sharing similar letters in a column do not differ significantly at $\mathrm{P}<0.05$, according to Fisher's LSD test LSD least significant difference, CV coefficient of variation, $\mathrm{T} 1=$ Control, $\mathrm{T} 2=100 \% \mathrm{RDF}, \mathrm{T} 3=2.5 \mathrm{t} \mathrm{CM}+25 \% \mathrm{RDF}, \mathrm{T} 4=2.5 \mathrm{tCM}+50 \% \mathrm{RDF}, \mathrm{T} 5 .=2.5 \mathrm{tCM}+75 \% \mathrm{RDF}, \mathrm{T} 6 .=5 \mathrm{t} \mathrm{CM}+25 \% \mathrm{RDF}$, $\mathrm{T} 7=5 \mathrm{t} \mathrm{CM}+50 \% \mathrm{RDF}, \mathrm{T} 8 .=5 \mathrm{t} \mathrm{CM}+75 \% \mathrm{RDF}, \mathrm{T} 9=7.5 \mathrm{t} \mathrm{CM}+25 \% \mathrm{RDF}, \mathrm{T} 10=7.5 \mathrm{t} \mathrm{CM}+50 \% \mathrm{RDF}, \mathrm{T} 11=7.5 \mathrm{t} \mathrm{CM}+75 \% \mathrm{RDF}$, RDF = Recommended Dose of mineral NP Fertilizer, $\mathrm{CM}=$ Cattle Manure in $\mathrm{tha}^{-1}$

\section{Conclusion}

Potato growth, development and high yield depend on soil properties, climatic conditions, the result of most of growth, biomass yield and quality of potato and indicated the fertility of the soil at Masha is very low and that is why all treatments with the combined use of cattle manure and mineral NP gave a higher biomass yield than the treatment with either no fertilizer or sole application of mineralNP, which gave a very low yield. Application of $\mathrm{CM}$ has a residual effect for the next cropping seasons. The combined application of mineral NP and cattle manure (CM) gave a better result than the application of sole, which indicates integrated nutrient management is the best method for soil fertility management. Hence, the usage of $165 \mathrm{~kg} \mathrm{~N}+60 \mathrm{~kg} \mathrm{P}+$ 7.5t $\mathrm{CMha}^{-1}$ can be recommended for better potato production, productivity, economic feasibility at abelo area Masha District. Yields varied slightly due to seasonal effects Yields were slightly higher in the short rainy (Belg) season than the long rainy( Meher) season the nutrients applied from mineral sources coupled with organic sources might have attributed to more availability of $\mathrm{N}$ that played a vital role in cell division. Similarly, reported lower dry matter content of tubers in the plot that receive nitrogen and $\mathrm{P}$ fertilization compared to the plot that did not receive $\mathrm{N}$ and $\mathrm{P}$ fertilizers in jalene potato variety. also reported low specific gravity of tubers at higher levels of NP of potato[56,57]. 
5. Satyanarayana V, Prasad PV, Murthy VRK, Boote KJ. Influence of integrateduse of cattle manure and minral fertilizers on yield and yield components of irrigated lowland rice. Journal of Plant Nutrition, 2002;25(10):2081-2090

6. Dejene $M$, Lemlem M. Integrated agronomic crop managements to improve teff productivity under terminal drought. 2012;235-254.

7. Kang Y, Hao Y, Shen M, Zhao Q Li Q Hu J. Impacts of supplementing chemical fertilizers with organic fertilizers manufactured using pig manure as a substrate on the spread of tetracycline resistance genes in soil. Ecotoxicology and Environmental Safety, 2016;130:279-288.

8. Godara AS, Gupta US, Singh R. Effect of integrated nutrient management on herbage, dry fodder yield, and quality of oat (Avena sativa L.) Forage Research, 2012;38(1):59-61.

9. Yadav SK, Babu S, Yadav MK, Singh K, Yadav GS, Pal S. A Review of Organic Farming for Sustainable Agriculture in Northern India International Journal of Agronomy, 2013:1-8.

10. Getachew Angachew. Ameliorating effects of organic and minral fertilizers on crop productivity and soil properties on reddish-brown soils. 2009;127-150.

11. Gafar AF, Yassin M, Ibrahim D, Yagoob SO. Effect of different (bio-organic and minral) fertilizers on some yield components of rice (Oryza sativa L.). Universal Journalof Agricultural Research, 2012;2(2):67-70.

12. Agegnehu Getachew ,Amede Tilahun. Integrated Soil Fertility and Plant Nutrient Management in Tropical Agro-Ecosystems: A Review. Pedosphere, 2017;27(4):662-680.

13.Zhu K, Christel W, Bruun S, Jensen LS. The different effects of applying fresh, composted or charred manure on soil N2O emissions. Soi Biology and Biochemistry, 2014;74:61-69.

14.Castellanos-Navarrete A, Tittonell P, Rufino MC, Giller KE. Feeding crop residue and manure management for integrated soil fertility management - A case study from Kenya. Agricultural Systems, 2015;134:24-35.

15. Daniel Mekonnen, and Niguse Dechassa. 2006. Effects of integrated nutrient management on agronomic performance of potato (Solanum tuberosum. L.) and fertility of Nitosol at Bako. MSc. Thesis. HaramayaUniversity, Haramaya, Ethiopia

16. Shiferaw Boke. Effect of organic and inorganic fertilizer application and seedbed preparation on potato yield and soil properties on alisols of chencha International Journal of Natural Sciences Research. 2014;2(8):123-132.

17. Biruk-Masrie Z, Nigussie-Dechassa R, Tamado Tana, YibekalA lemayehu, Bekele Abebi. Effect of Application of Cattle Manure and Mineral NP Fertilizers on Yield, and Nutrient Uptake of Potato in NorthEastern Ethiopia. Journal of Science and Sustainable Development, in press. 2015;

18. Kassa H, Dondeyne S, Poesen J, Frankl A, Nyssen J. Transition from forest- to cereal-based agricultural systems: a review of the drivers of land-use change and degradation in southwest Ethiopia. Land Degradation \& Development, 2016;28(2):431-449.

19. Day PR. Hydrometer method of particle size analysis. In: C.A. Black (ed.). Methods of soil analysis. Agronomy Part I, No. 9. American Society of Agronomy. Madison, Wisconsin, USA. pp. 1965;562-563.

20. Page AL. Methods of Soil Analysis. Part II. Chemical and Microbiological Properties. 1982;
21. Jackson ML. Soil Chemical Analysis. Prenstice-Hall, Inc., Engle Wood Cliffs. New Jersey. 1958;183-204.

22. Walkley AJ, Black IA. Estimation of soil organic carbon by the chromic acid titration method. Soil Science. 1934;37:29-38.

23. Bray RH, A Kurtz. Determination of total, organic and available forms of phosphorousin soils. Soil Science, 1945; 59(1):39-45.

24.FAO (Food and Agriculture Organization).Plant nutrition for food security: A guide for integrated nutrient management. FAO, fertilizer and plant nutrition bulletin 16, Rome. Italy. 2006;

25. Lung aho C, B Lemaga, M Nyongesa, P Gildermacher, P Kinyale, P Demo and J. Kabira . Commercial seed potato production in eastern and central Africa. Kenya Agricultural Institute. 2007;140p

26. Bonierbale M, Steff de Hann A, Forbes. Procedures for standard evaluation trials of advanced potato clones:An International Cooperators' Guide. International Potato Centre (CIP). 2006;124

27.SAS (Statistical Analysis System). 2003. SAS Version 9. 1.2 (c) 20022003". SAS Institute, Inc., Cary, North Carolina, USA

28. Tekalign Tadesse, Haque L, Aduayi EA. Soil, Plant, Water, Fertilizer, Animal Manure and Compost Analysis Manual: Plant Science Division Working Document NO. 13. International Livestock center for Africa. 1991;

29. Black, CA. 1965. Methods of soil analysis. American Society of Agronomy, 1: 1570-1572.

30. Barauah TC, Barthakulh HP. A textbook of soil analysis. Vikas Publishing House. New Delhi, India. 1997;334.

31. Ritchey E, Murdock L. Lime and Nutrient Recommendations. Cooperative extension service - university of Kentucky college of agriculture, Lexington, ky, 2013;40546

32. Isreal Zewide, Ali Mohammed and Solomon Tulu Tadesse. Potato (Solanum tuberosum L.) Growth and Tuber Quality, Soil Nitrogen and Phosphorus Content as Affected by Different Rates of Nitrogen and Phosphorus at Masha District in Southwestern Ethiopia. International Journal of Agricultural Research, 2016;11:95-104.

33. Amir Al N, Reza M, Seyed H, Darzi MT. Influence of nitrogen fertilizer and cattle manure on the vegetative growth and tuber production of potato. 2013;5(2):147-154.

34.AbayAyalew , Tesfaye Dejene. Integrated Application of Compost and Minral Fertilizers for Production of Potato (Solanum tuberosum 1.) at Angacha and Kokate in Southern Ethiopia Journal of Biology, Agriculture and Healthcare, 2011;1(2):1-24

35. Kumar M, Baishya LK, Ghosh DC, Ghosh M, Gupta VK, Verma MR. Effects of organic manures, chemical fertilizers and biofertilizers on growth and productivity of rainfed potato in the eastern himalayas. Journal of Plant Nutrition, 2013;36(7):1065-1082.

36. Balemi T. Effect of integrated use of cattle manure and inorganic fertilizers on tuber yield of potato in Ethiopia. J. Soil Sci. Plant Nutr. 2012;12(2):257-265.

37. Najm AA, Hadi MRH S, Fazeli F, Darzi MT, Rahi A. Effect of Integrated Management of Nitrogen Fertilizer and Cattle Manure on the Leaf Chlorophyll, Yield, and Tuber Glycoalkaloids of Agria Potato. Communications in Soil Science and Plant Analysis. 2012;43(6);912923.

38. Tsegaye Girma, Sheleme Beyene, Berhanu Biazin. Effect of Organic and Inorganic Fertilizer Application on Soil Phosphorous Balance and 
Phosphorous Uptake and Use Efficiency of Potato in Arbegona District, Southern Ethiopia Journal of Fertilizers and Pesticides, 2017;8(3):185.

39. Suh C, Meka SS, Ngome AF, Neba DA, Kemngwa IT, Sonkouat AD, 1Njualem D. Full Length Research Article (Solanum tuberosum L.) In the western highlands of Cameroon, 2015;5:3584-3588.

40. Ahmed AA, Zaki MF, Shafeek MR, Helmy YI, and El-baky, M. MHA. Original Research Article Integrated use of Cattle Manure and Minral Nitrogen Fertilizer on Growth, Yield, and Quality of Potato ( Solanum tuberosum L.), International .Journal .Current.Microbiol.Applied. Science, 2015;4(10):325-349.

41. Fekadu Asfaw. Effect of Integrated Soil Amendment Practices on Growth and Seed Tuber Yield of Potato (Solanum tuberosum L.) at JimmaArjo, Western Ethiopia Journal of Natural Sciences Research, 2016;6(15):1-26.

42. Israel Zewide, Ali Mohammed, Solomon Tulu. Potato (Solanum tuberosum L.) Growth and Tuber Quality, Soil Nitrogen and Phosphorus Content as Affected by Different Rates of Nitrogen and Phosphorus at Masha District in Southwestern Ethiopia. 2016;11(3):95-104.

43. Azarmi R, Giglou MT, Taleshmikail RD. Influence of vermicompost on soil chemical and physical properties in tomato ( Lycopersicumesculentum ) African Journal of Biotechnology, 2008;7(14):2397-2401.

44. Abadi ZA, Sepanlou MG, Bahmanyar MA. The effect of municipal compost application on the amount of micro elements and their absorption in soil and medicinal plant of mint (Menthas). Afr J Biotechnol. 2011; 10(77):17716-17725.

45. Nada WM, Rensburg LV, Claassens S, Blumenstein O. Effect of vermicompost on soil and plant properties of coal spoil in the Lusatian region (Eastern Germany). Commun Soil Sci Plant Ana 2011;42(16):1945-1957.

46. Lauren P, Margenot A, Six J, Scow K. On-farm trial assessing combined organic and mineral fertilizer amendments on vegetable yields in central Uganda. Agriculture, Ecosystems and Environment, 2016;225:62-71

47. Simon-koroto, FikreyohannesGedamu and Tamado Tana 2017.Effect of Farmyard Manure and Mineral NP Fertilizers on Yield Related Traits and Yield of Potato (Solanum tuberosum L.) At Areka, Southern Ethiopia A MSc. Thesis. Haramaya University, Haramaya

48. Brijesh R, Singh BN, Kumar H. Impact of Various Organic Treatments on Growth, Yield and Quality Parameters of Potato, 2017;5(3):643647.

49. Hazelton P, Murphy B. Interpreting Soil Test Results. What do all the numbers mean? 2nd (ed.).CSIRO Publishing. 2007.

50. Bationo A, Waswa B, Okeyo J, Maina F, Kihara J. Innovations as Key to the Green Revolution in Africa. Springer, Dordrecht. 2011;

51.In: I. Md. M. Rahman and H. Hasegawa, (eds.), Water Stress, In Technology Open Science EthioSIS (Ethiopia Soil Information System) 2014.
52. Soil fertility status and fertilizer recommendation atlas for Tigray regional state, Ethiopia. 2014

53.FAO (Food and Agriculture Organization).Plant nutrition for food security: A guide for integrated nutrient management. FAO, fertilizer and plant nutrition bulletin 16, Rome. Italy. 2006;

54. Proceeding of the tenth Conference of the Ethiopian Society of Soil Science. 25-27 March 2009, held at EIAR, Addis Ababa, Ethiopia

55. Gomez KA, AA Gomez. Statistical Procedures for Agricultural Research. Johnwiley and Sons, Newyork. 1984;704.

56. Hazelton P, Murphy B. Interpreting Soil Test Results: What do all the numbers Mean 2nd (eds.). CSIRO Publishing. 2007;152.

57. Hillel D. Introduction to Environmental Soil Physics. Elsevier Academic Press. 2014;

58. Jones JB. Agronomic Handbook: Management of Crops, Soils, and Their Fertility. CRC Press LLC, Boca Raton, FL, USA.2003;482.

59. Kleinkopf GE, DT Westermann. Specific Gravity of Russet Burbank Potatoes. American Potato Journal. 1987;64(11):579-587.

60. Kuldeep Balai, M Jajoria, R Verma, P Deewan, SK Bairwa. Nutrient content, uptake, quality of chickpea and fertility status of soil as influenced by fertilization of Phosphorous and Zinc. Journal of Pharmacognosy and Phytochemistry, 2016;6(1):392-398.

61. Landon JR. Booker Tropical Soil Manual: A Handbook for Soil Survey and Agricultural Land Evaluation in the Tropics and Subtropics. Longman Scientific and Technical, Essex, New York. 1991;474.

62. MoARD (Ministry of Agriculture and Rural Development). 2012. Crop Development Department of Crop Variety Register. Issue No. 10. Addis Ababa, Ethiopia.

63. Suresh Kumar Kakraliya, Jat RD, Sandeep Kumar, KK Choudhary Jai Prakash, LK. Singh. Integrated Nutrient Management for Improving, Fertilizer Use Efficiency, Soil Biodiversity and Productivity of Wheat in Irrigated Rice Wheat Cropping System in Indo-Gangatic Plains of India International. Journal Current. Microbiol. 2017;6(3):152-163.

64. Israel Zewide,Tamado Tana ,Lemma Wog , and Ali Mohammed.2018. Soil Morphology, Physico-Chemical Properties and Classification of Typical Soils of Abelo Area Masha District South Western Ethiopia. Advances in Crop Science and Technology, 6

65. Zhao J, Ni T, Li J, Lu Q Fang Z, Huang Q et al. Effects of organic-inorganic compound fertilizer with reduced chemical fertilizer application on crop yields, soil biological activity and bacterial community structure in a rice-wheat cropping system. Applied Soil Ecology, 2016;99:1-12.

66. Biruk-Masrie Z., Nigussie-Dechassa R., Tamado Tana, Yibekal Alemayehu and Bekele Abebi, 2015. Effect of Application of Cattle Manure and Mineral NP Fertilizers on Yield, and Nutrient Uptake of Potato in North-Eastern Ethiopia. Journal of Science and Sustainable Development, 3(1): 1-23.

67. MoARD (Ministry of Agriculture and Rural Development). 2012. Crop Development Department of Crop Variety Register. Issue No. 18. Addis Ababa, Ethiopia. 